\title{
The 2017, MD = 4.0, Casamicciola Earthquake: ESI-07 Scale Evaluation and Implications for the Source Model
}

\author{
Rosa Nappi ${ }^{1, *(\mathbb{C})}$, Sabina Porfido ${ }^{1,2}{ }^{(0)}$, Elisa Paganini ${ }^{3}$, Luigina Vezzoli ${ }^{3}$, Maria Francesca Ferrario ${ }^{3}{ }^{(1)}$, \\ Germana Gaudiosi ${ }^{1}$, Giuliana Alessio ${ }^{1}$ (D) and Alessandro Maria Michetti ${ }^{3}[$ \\ 1 Istituto Nazionale di Geofisica e Vulcanologia, Sezione di Napoli Osservatorio Vesuviano, \\ Via Diocleziano, 328, 80124 Napoli, Italy; sabina.porfido@cnr.it (S.P.); germana.gaudiosi@ingv.it (G.G.); \\ giuliana.alessio@ingv.it (G.A.) \\ 2 Consiglio Nazionale delle Ricerche-ISA, Via Roma 64, 80100 Avellino, Italy \\ 3 Dipartimento di Scienza e Alta Tecnologia, Università Degli Studi Dell'insubria, 22100 Como, Italy; \\ elisa.paganini.96@gmail.com (E.P.); luigina.vezzoli@uninsubria.it (L.V.); \\ francesca.ferrario@uninsubria.it (M.F.F.); alessandro.michetti@uninsubria.it (A.M.M.) \\ * Correspondence: rosa.nappi@ingv.it; Tel.: +081-610-8324
}

check for updates

Citation: Nappi, R.; Porfido, S.; Paganini, E.; Vezzoli, L.; Ferrario, M.F.; Gaudiosi, G.; Alessio, G.; Michetti, A.M. The 2017, MD = 4.0, Casamicciola Earthquake: ESI-07 Scale Evaluation and Implications for the Source Model. Geosciences 2021, 11, 44. https://doi.org/10.3390/ geosciences 11020044

Received: 9 December 2020

Accepted: 18 January 2021

Published: 22 January 2021

Publisher's Note: MDPI stays neutral with regard to jurisdictional claims in published maps and institutional affiliations.

Copyright: (c) 2021 by the authors. Licensee MDPI, Basel, Switzerland. This article is an open access article distributed under the terms and conditions of the Creative Commons Attribution (CC BY) license (https:// creativecommons.org/licenses/by/ $4.0 /)$.

\begin{abstract}
On 21 August 2017 at 20:57 (local time) a very shallow $(\mathrm{H}=1.2 \mathrm{~km})$, moderate $(\mathrm{Md}=4.0)$, earthquake hit the volcanic island of Ischia (Southern Italy), causing the death of two people. The study of the damage to the buildings with the European Macroseismic Scale 98 (EMS-98), carried out immediately after the earthquake, highlighted that hilly area of Casamicciola Terme, on the northern side of the Mt. Epomeo, was the most damaged part of the island with locally quite relevant damage ( $\mathrm{I}=$ VIII EMS). This seismic event is the first damaging earthquake in Ischia during the instrumental era. In fact, this provides, for the first time, the opportunity to integrate historical seismicity, macroseismic observations, instrumental information, and detailed mapping of the geological coseismic effects. In this work we evaluate the effects induced by the 2017 Casamicciola earthquake on the environment using the Environmental Seismic Intensity 2007 (ESI-07) macroseismic scale. This macroseismic analysis, together with the superficial coseismic faulting characteristics and the available geophysical information, allows us to reconsider the source model for the 2017 earthquake and the previous damaging historical earthquakes in the Casamicciola Terme area. The application of the ESI scale to the Casamicciola Terme earthquake of 21 August 2017 and the assignment of seismic intensity offers better spatial resolution, as well as an increase of the time window for the assessment of the seismic hazard, allowing to reduce the implicit uncertainty in the intensity attenuation laws in this peculiar volcano-tectonic setting. Since intensity is linked to the direct measure of damage, and it is commonly used in hazard assessment, we argue that building damage at Casamicciola Terme is strongly influenced by earthquake surface faulting and near field effects, and therefore controlled by the geometry of the seismic source.
\end{abstract}

Keywords: macroseismic intensity; ESI 2007 scale; 2017 Casamicciola earthquake; fault model; capable fault; volcanotectonic seismicity

\section{Introduction}

The 21 August 2017, Md 4.0 Casamicciola Terme earthquake (Latitude N40.74 , Longitude E13.90 ${ }^{\circ}$ [1] (Figure 1) is the first damaging earthquake recorded on the volcanic island of Ischia (Gulf of Naples, southern Italy) along the instrumental era. The earthquake occurred during the summer season, at 19:57 GMT, with peak tourist presence in the Ischia Island. The hypocentral depth was very shallow, about $1.2 \mathrm{~km}$; focal mechanism and geological effects strongly suggests an E-trending, steep normal fault plane as the seismogenic source [2-4] (Figures 1 and 2). The main event was followed by 27 aftershocks in the following months, characterized by Md between 0.7 and 1.9. 
The earthquake severely damaged the hilly sector of the municipality of Casamicciola Terme, causing two deaths and significant ground effects. Immediately after the mainshock, a macroseismic study was performed using the European Macroseismic Scale 98 (EMS98) $[5,6]$. The most damaged part of the island was found to be the hilly area of Casamicciola Terme, on the northern slope of Mt. Epomeo. The coastal zone of the municipality, near the port, was not particularly affected, presenting slight but widespread damage $(\mathrm{I}=\mathrm{VI}$ EMS). In the piedmont area of Casamicciola Terme, however, the damage was locally quite significant. In this area there were few total collapses, some partial collapses, cross injuries, loss of verticality, overturning of walls and ejection of edges; reinforced concrete buildings showed rare cases of minor damage $(\mathrm{I}=$ VIII EMS). Widespread damage was also observed in the Fango and Lacco Ameno locality (I = VII EMS), while sporadic and very slight damages $(\mathrm{I}=\mathrm{V}$ EMS) were reported in the remaining municipalities [5-8].

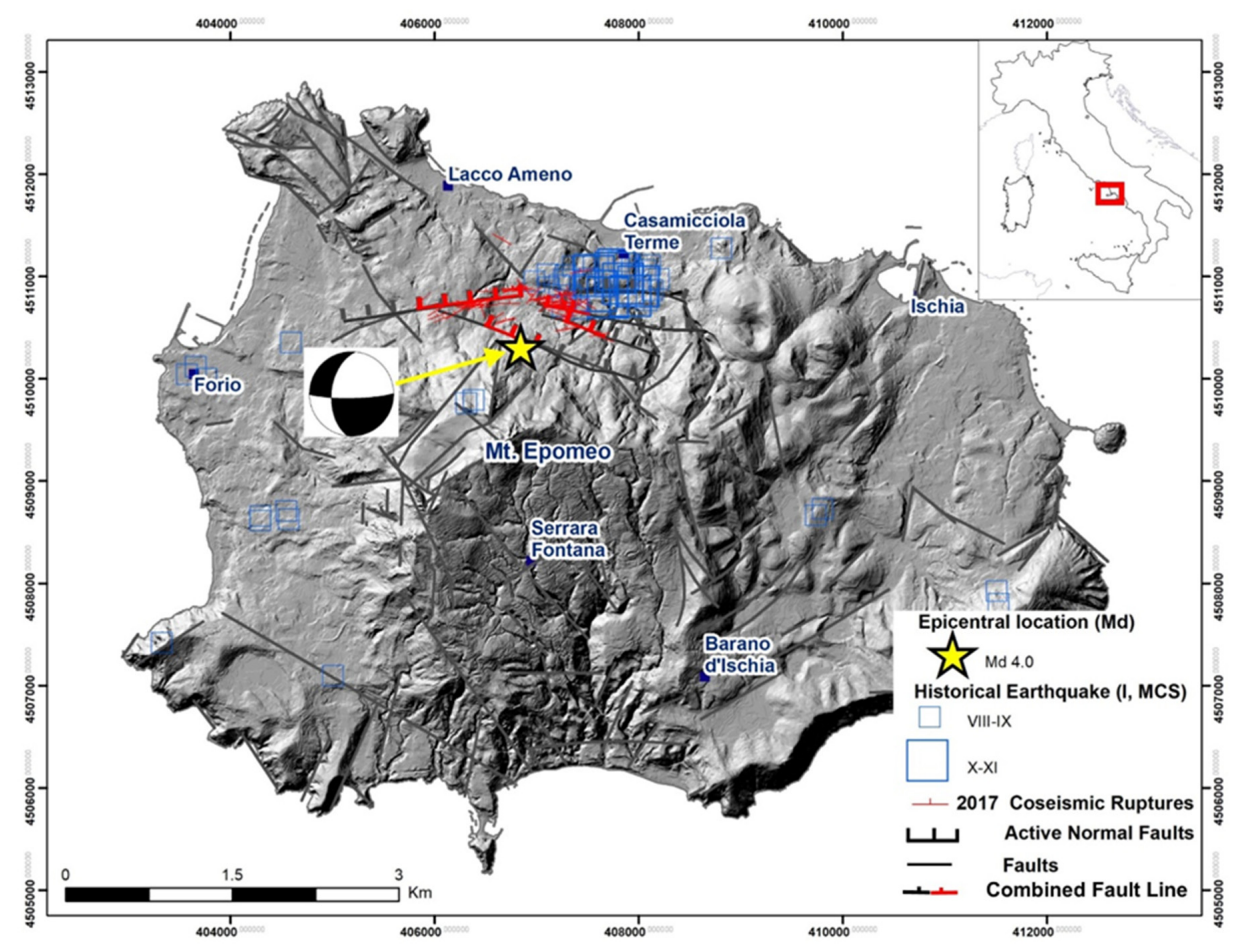

Figure 1. Seismotectonic setting of the 21 August 2017, Ischia Island earthquake; red lines show coseismic ruptures mapped by [4]; black lines, active normal faults from [9-14]; grey lines, other faults of the Ischia Volcano [11-13]; cyano squares, historical seismicity from [14] (macroseismic scale MCS, Mercalli-Cancani-Sieberg; [15]); yellow star shows the mainshock, Md 4.0, with its focal mechanism for the 2017 seismic event from [2]; inset map, the study region in a larger location map of Italy. 


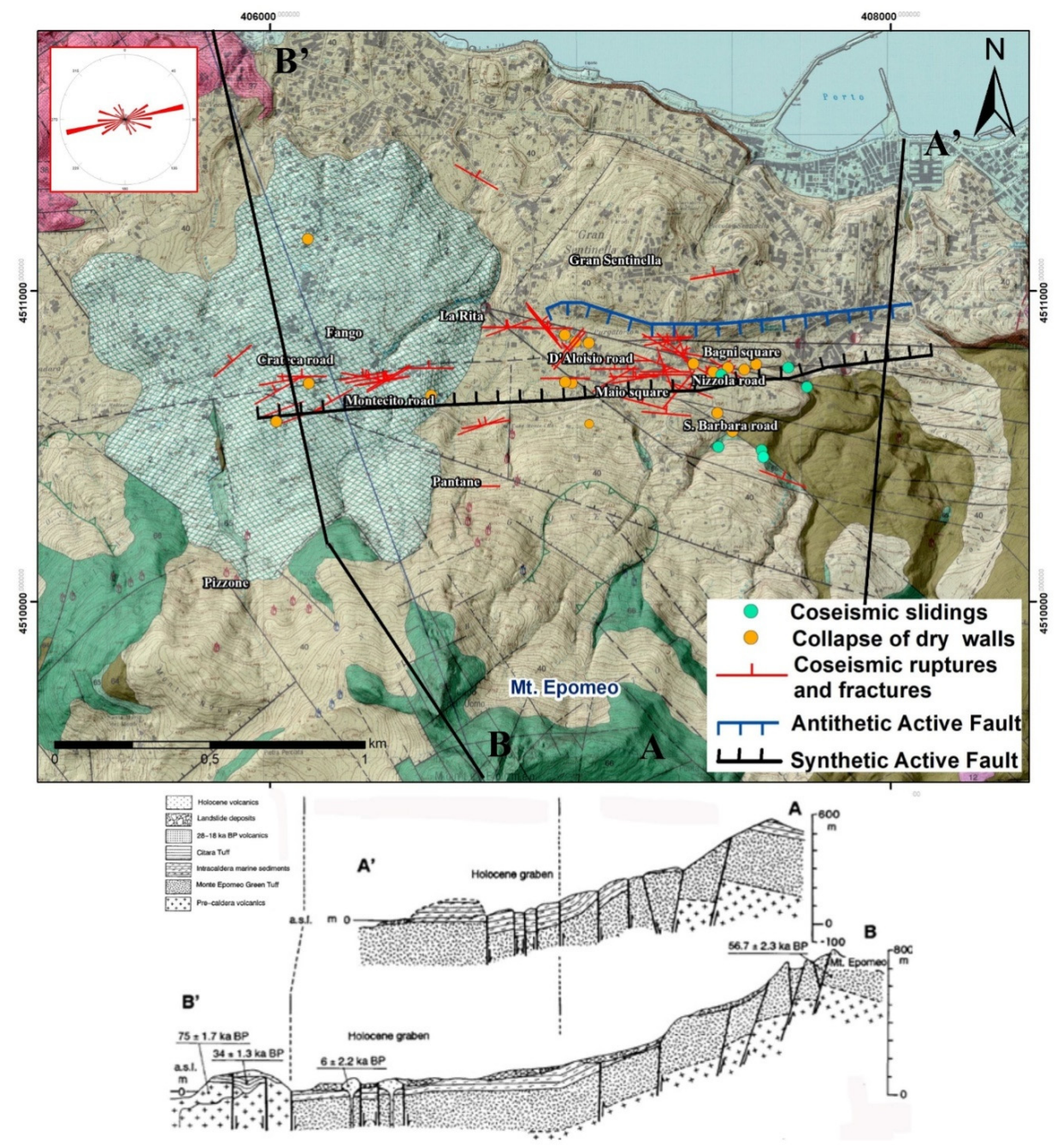

Figure 2. Top, map of the coseismic ruptures, secondary environmental effects and collapse of drywall (data reported because located in the immediate vicinity of ground effects) in the epicentral area of the 21 August 2017, earthquake [4], overlapped on the geological map of [16]; black line is the synthetic active fault and blu line is the antithetic Holocene normal fault scarps of the Casamicciola Terme graben (ticks mark the downthrown side); bottom, geological cross-sections of the epicentral area, with structural details of the Holocene graben [9], trace location on the top.

The Casamicciola earthquake is in fact the first damaging seismic event occurred in Ischia island which has been relatively well documented by seismological, geodetic, geophysical and geological data, can propose different source models for the earthquake [1-4,17-21].

In particular, the geological analysis of the ground effects was carried out immediately after the main shock, through more than 100 field observations [4,22,23], including both primary (surface ruptures directly related to the earthquake causative fault; [24-27], Figures 1 and 2) and secondary (mostly related to ground shaking, such as landslides and hydrological variations) effects. Based on the careful analysis of the local geological and structural setting, [4] proposed a primary tectonic origin for the mapped ground ruptures, interpreted as the propagation up to the surface of the seismogenic motion occurred at depth.

Similar to strong crustal earthquakes, the characterization of coseismic surface effects of very shallow volcanic events provides constraints on the earthquake source parameters and the long-term behavior of active faults (amount of displacement, slip-rates, geometry, style of faulting; e.g., [28,29]). Such observations support studies on the mechanics of earthquake faulting and are used to refine modeling of the seismic sources based also on joint geophysical datasets of the damaging earthquakes. In fact, at the Ischia Island, the epicentral location of destructive pre-instrumental earthquakes $[14,30,31]$ is systematically 
confined to the same area of few square kilometers near Casamicciola Terme, in which clear stratigraphic and morphological evidence of the seismo-tectonic activity is represented by a Holocene graben at the base of the northern flank of Mt. Epomeo [4,9,10,32] (Figures 1 and 2). The graben includes the 21 August 2017 epicentral area and the epicentral areas of all the damaging seismic events (Table 1) in the last three centuries, notably those of the very strong earthquakes occurred in 1796, 1828, 1881, and 1883 [14,31], and it was formed as a result of extensional tectonic deformation during the last phase of Ischia caldera resurgence $[16,33]$. Therefore, the 2017 earthquake can be considered as a reference seismic event for the future calibration of the entire historical Ischia seismic dataset, and for the assessment of earthquake hazard in this peculiar volcano-tectonic environment.

Table 1. MaIn historical earthquakes of The Ischia island since The 13th century and The relative observed environmental phenomena.

\begin{tabular}{|c|c|c|c|c|c|c|}
\hline Date & Lat. $\mathbf{N}$ & Long. E & Epicenter & $\begin{array}{l}\text { Epicentral } \\
\text { Intensity } \\
\text { MCS }\end{array}$ & $\begin{array}{c}\text { Mw } \\
\text { (From Macroseismic } \\
\text { Data) }\end{array}$ & Environmental Effects \\
\hline 2 November 1275 & 40.733 & 13.917 & Ischia & VIII-IX & 4.0 & Landslides \\
\hline 1302 & - & - & Ischia & VIII & - & ARSO Eruption/Landslides \\
\hline 1557 & 40.721 & 13.953 & Ischia & VI-VII & 3.5 & - \\
\hline 23 July 1762 & 40.746 & 13.909 & $\begin{array}{l}\text { Casamicciola } \\
\text { Terme }\end{array}$ & VII & 3.5 & - \\
\hline 1767 & 40.735 & 13.919 & $\begin{array}{l}\text { Casamicciola } \\
\text { Terme }\end{array}$ & VII-VIII & 3.5 & Landslides \\
\hline 18 March 1796 & 40.746 & 13.909 & $\begin{array}{l}\text { Casamicciola } \\
\text { Terme }\end{array}$ & VIII & 3,8 & Landslides \\
\hline 2 February 1828 & 40.746 & 13.909 & $\begin{array}{l}\text { Casamicciola } \\
\text { Terme }\end{array}$ & VIII-IX & 4.0 & $\begin{array}{l}\text { Landslides /Fractures/ } \\
\text { Hydrothermal variation (fumaroles) }\end{array}$ \\
\hline 6 March 1841 & 40.749 & 13.899 & $\begin{array}{l}\text { Casamicciola } \\
\text { Terme }\end{array}$ & VI & 3.2 & - \\
\hline 1863 & 40.746 & 13.909 & $\begin{array}{l}\text { Casamicciola } \\
\text { Terme }\end{array}$ & $\mathrm{V}$ & 2.8 & $\begin{array}{l}\text { Landslides } \\
\text { Hydrothermal variation (fumaroles) }\end{array}$ \\
\hline 1867 & 40.746 & 13.909 & $\begin{array}{l}\text { Casamicciola } \\
\text { Terme }\end{array}$ & V-VI & 2.9 & - \\
\hline 4 March 1881 & 40.747 & 13.895 & $\begin{array}{l}\text { Casamicciola } \\
\text { Terme }\end{array}$ & IX & 4.1 & $\begin{array}{l}\text { Landslides/Fractures/ } \\
\text { Hydrothermal and hydrological } \\
\text { variation (fumaroles) }\end{array}$ \\
\hline 28 July 1883 & 40.744 & 13.885 & $\begin{array}{l}\text { Casamicciola } \\
\text { Terme }\end{array}$ & XI & 5.2 & $\begin{array}{l}\text { Landslides/Fractures/Hydrothermal } \\
\text { and hydrological changes }\end{array}$ \\
\hline
\end{tabular}

In this paper, we evaluate the effects induced by the Casamicciola 2017 earthquake on the environment using the Environmental Seismic Intensity 2007 (ESI) macroseismic scale $[26,27,34]$. The ESI scale integrates the traditional macroseismic scales, of which it represents an evolution, allowing to assess the intensity parameter on the basis of environmental effects, also where buildings are absent, and when damage-based diagnostics are also saturated. This macroseismic analysis, together with the study of coseismic surface faulting characteristics and available geophysical information, allows us to reconsider the source model for the 2017 earthquake and previous damaging events in the Casamicciola Terme area.

The construction of a descriptive sheet attached as supplementary files to this work (Table S1) of the environmental effects allowed the estimation of the degrees of ESI intensity, the comparison with other macroseismic datasets, and the reconstruction of the isoseismal map. Since intensity is linked to the direct measure of damage, and it is commonly used in hazard assessment [35-37], the aim of the study is also to argue, through the isoseismal evaluation, that building damage at Casamicciola Terme is essentially linked to observed surface faulting and therefore influenced by the geometry of the seismic source. 


\section{Geological and Volcanological Setting}

Ischia is an active volcanic island on the NW side of the Gulf of Naples and belongs to the Campanian volcanic province, which includes the Campi Flegrei. The island is the subaerial portion of a volcanic complex that has been active since at least $150 \mathrm{ka} \mathrm{BP}$ [16].

The main structural elements consist of a caldera rim located along the perimeter of the island, and the structural and morphological relief of Mt. Epomeo, culminating at $787 \mathrm{~m}$ a.s.l. and interpreted as a volcano-tectonic "horst" [16,38,39] resulted from a Late Pleistocene to Holocene caldera resurgence. The volcanic activity of the island was dominated by the caldera-forming Green Tuff eruption $55 \mathrm{ka}$ BP. This was followed since at least $30 \mathrm{ka}$ BP by block resurgence within the caldera [40]. The last period of volcanic activity started $10 \mathrm{ka} \mathrm{BP}$, with eruptions in the eastern sector of the island, including the most recent eruption of Arso in 1302 [13,41]. The resurgence phenomena, attributed to repeated injections of new magma in a surface magma chamber at depths of $2-3 \mathrm{~km}[9,11,31,33,38,40,42-47]$ is responsible for the asymmetric morphology of the Ischia topographic relief, with a NW topmost uplift and a subsidence towards SE.

The ca. E-W normal fault system (Figures 1 and 2) that borders the $\mathrm{N}$ flank of the Mt. Epomeo is responsible for a maximum vertical displacement towards the $N[4,9,11-13,16,40,48]$ and for the maximum recent uplift, estimated at $920-970 \mathrm{~m}$. Marine deposits outcropping near the summit of Mt. Epomeo have been dated at ca. $30 \mathrm{ka} \mathrm{BP}$, yielding a mean uplift rate of $33 \mathrm{~mm} / \mathrm{yr}$, regarded as one of the highest measured at any volcano [33,48,49]. The $\mathrm{N}$ flank of the uplifted block is separated from the more stable coastal area by a system of E to ENE trending parallel normal faults that dip $60-85^{\circ} \mathrm{N}$, which in the piedmont area of Casamicciola Terme is accompanied by an antithetic S-dipping segment producing a morphologically well-defined Holocene graben structure in the hanging wall $[9,10]$ (Figure 2). The Casamicciola Terme graben marks the center of the 21 August 2017, earthquake epicentral area [1,4-6] (Figure 2).

The high precision leveling from 1987, 2003, 2010, and 2018 campaigns, together with the measurements from continuous Global Positioning System (cGPS), tiltmetric monitoring networks, as well as Interferometric Synthetic Aperture Radar (InSAR) imagery have shown the existence in the past decades, since 1913, of a phase of general subsidence, of as much as $10 \mathrm{~mm} / \mathrm{yr}$ across the south-central part of the island [50-52], including a local NW ground subsidence, observed also after the 21 August 2017, Casamicciola earthquake [18].

The Mt. Epomeo border fault triggered shallow ( $<2 \mathrm{~km}$ depth) and destructive earthquakes in the last three centuries, systematically centered in the Casamicciola Terme area (Figure 1): 1796, 1828, 1881, 1883, and 2017, with epicentral intensity between VIII and XI MCS (Table 1) [2,4,14,20,30,53-56].

Combined with the seismic activity and the presence of the hydrothermal system, the high rate of resurgence has produced steep slopes on the flanks of Mt. Epomeo. The steep angles and geotechnical properties of the outcropping weathered Green Tuff, have favored slope instability resulting in shallow mass movements, in large rock and debris avalanches [57-60].

\section{Seismicity of the Ischia Island}

The first reliable information on the seismicity of Ischia dates back to the earthquake of the thirteenth century, although more complete information on seismicity is only available at the end of the 18th century, when a substantial seismic activity began which developed further in the following century. Seismic events in Table 1 are all characterized by a recurrence of the epicenters north of Mt. Epomeo, in particular in the hilly part of the municipality of Casamicciola Terme, and by a strong epicentral intensity (I > VII MCS) which decreases rapidly with increasing distance from the epicenter (Figure 3). The most catastrophic earthquakes occurred on 4 March 1881 (Io = IX MCS), [14]) and on 28 July 1883 (Io = XI MCS) and with macroseismically estimated magnitude Me of 4.3-5.2 [30]. Both events destroyed Casamicciola village and its surroundings, killing 120 and injuring 140 people in 1881, and claiming 2343 lives in 1883. The 1881 and 1883 macroseismic 
fields show E-W elongated isoseismals along the $\mathrm{N}$ sector of the island between Lacco Ameno and Bagni Square in Casamicciola Terme [14,61]. The 1883 earthquake to date is the known event with the highest epicentral intensity and magnitude; occurred only two years after the catastrophic 1881 Io = IX MCS event, it was followed by fast emergency building reconstruction so as not to compromise the prosperous tourist season of the time. The extremely severe XI MCS intensity value observed in the epicentral area for the 1883 earthquake can be ascribed to different factors including (i) the highly destructive effects of the very shallow causative fault; (ii) the site amplification problems due to the complex lithological variations in the epicentral area; and (iii) the poor quality of building construction at the time $[14,30,38,53,57,58,62]$.

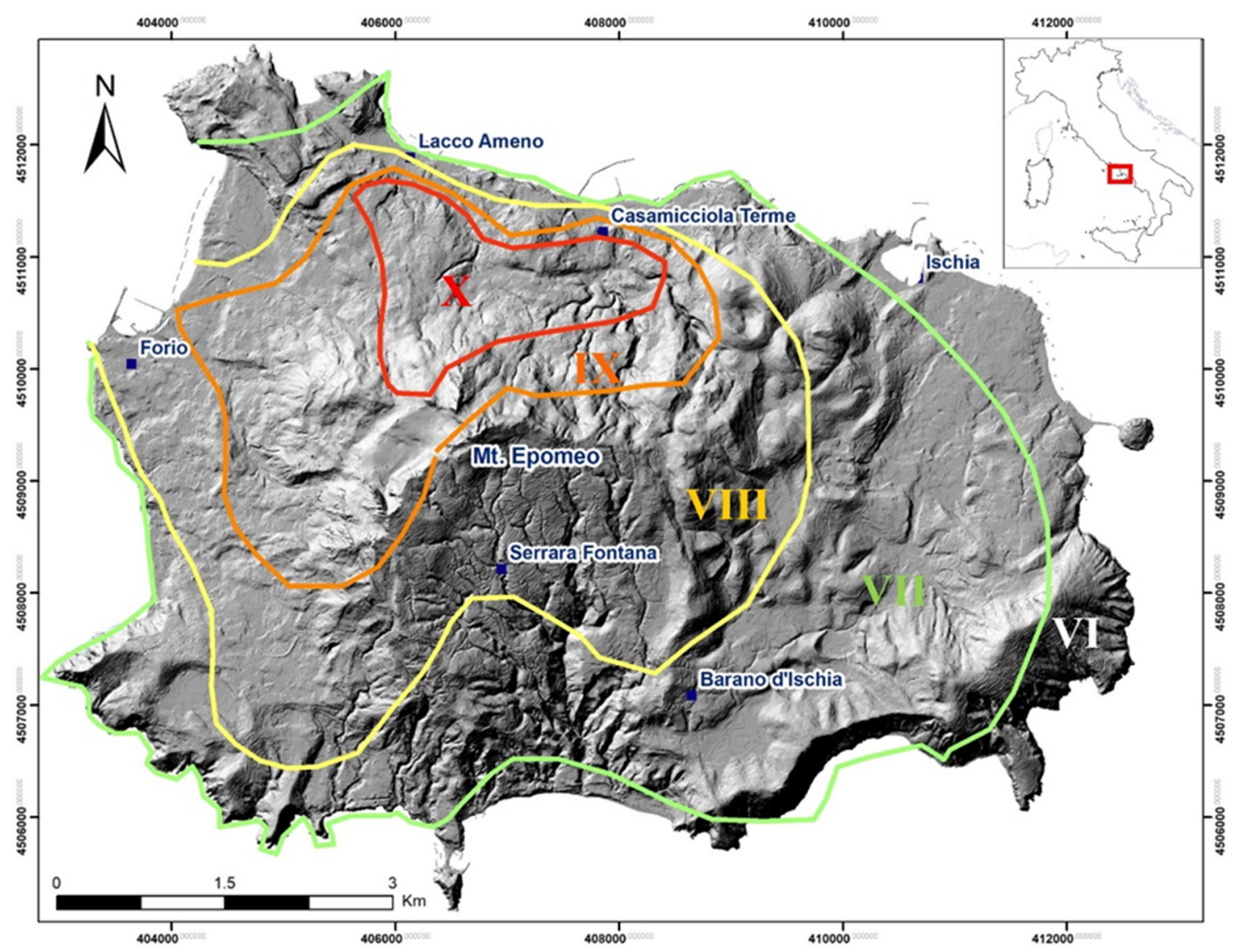

Figure 3. Isoseismal map of the Casamicciola Terme earthquake of 28 July 1883 (MCS scale); the epicentral area of X MCS develops on the N side of Mt. Epomeo, affecting Casamicciola Terme and Lacco Ameno; the isoseismal of greater intensity show an E-W and N-S elongation, while the isoseismal of a lower degree border the Epomeo simulating channeling pro cesses of the seismic energy released at the source [30].

In the 20th century, before the 2017 earthquake, only low intensity events were detected in the northern sector of the island, which did not cause relevant damage. Since 1999 about 50 events with Ml 2.3 or less and depths shallower than $2 \mathrm{~km}$ have been recorded by the three seismic stations of the permanent Ischia seismic network of the Istituto Nazionale di Geofisica e Vulcanologia-Osservatorio Vesuviano [56,63].

The overall seismicity of the Ischia island has clear volcano-tectonic character with shallow hypocenters (less than $2 \mathrm{~km}$ ), located mostly on the northern flank of Mt. Epomeo (Figures 1 and 2; Table 1). The maximum observed MCS intensities range between VII and XI [4] decreasing rapidly in value with distance from the epicenters [14,30,62,64]. Moreover, the Ischia earthquakes are characterized by rapid attenuation of intensity with the distance. As already noted, the effects of earthquakes are repeated with similar characteristics along a belt of normal faults bordering the $\mathrm{N}$ flank of Mt. Epomeo (Figures 1 and 2). 
The tectonic framework of the island does not allow to exclude a reactivation of seismogenic structures, but the geological conditions of the island, the reduced thickness of the fragile layer and for its intense fracturing, exclude the occurrence of strong crustal earthquakes $[44,65]$. It is important to recall, however, that a high-magnitude event is not necessary to cause significant damage to the territory; as already occurred in the past, an earthquake with $\mathrm{M}=4.0$ was sufficient to generate a degree of damage of I $\geq$ VIII MCS. The high thermal gradients on the island, even higher than $150{ }^{\circ} \mathrm{C} / \mathrm{km}$, indicate the presence of high temperature rocks at shallow depths, on the roof of which a colder layer of about $2 \mathrm{~km}$ thick develops. High temperature rocks have a ductile behavior and are therefore unable to accumulate elastic energy. These conditions seem confirmed by the small seismogenic volumes of these low-energy seismic events recorded on the island in historical times. In particular, the $S$ sector of Ischia Island is virtually aseismic $[19,56,64]$, while all recorded damaging events are located in the area of Casamicciola Terme along the $\mathrm{N}$ slope of Mt. Epomeo.

\section{ESI 2007 Macroseismic Field Reconstruction}

Generally, earthquakes induce effects on people, buildings, manmade infrastructure, and environment. The traditional macroseismic scales (MCS, Mercalli Cancani Sieberg [15]; MM, Modified Mercalli [66]; MSK, Medvedev-Sponheuer-Karnik [67]; EMS, European Macroseismic Scale, [68]) assess the intensity value on the basis of damage to buildings and infrastructures; this can be difficult for degrees of intensity higher than $\mathrm{X}$ or when the macroseismic fields of multiple seismic events close in time overlap. Traditional macroseismic scales have some drawbacks, such as the strong dependence on the spatial distribution of buildings, their type and characteristics, and saturation in the case of high intensity degrees (I > IX MCS).

A complementary approach is to assign the intensity through the ESI 2007 scale. The ESI 2007 is a new intensity scale based on environmental effects [26,34]. It is a staircase structured in XII degrees. The environmental seismic effects, considered diagnostic to evaluate the intensity, are divided into primary and secondary effects. Primary effects are the effects directly linked to the source of the earthquake, such as surface faulting and regional tectonic uplift or subsidence. Secondary effects are the effects related to seismic shaking, such as ground fractures, liquefaction, lateral spreading, slope movements, landslides, rock fall, tsunamis, hydrogeological variations, and dust cloud formation [25,26]. Between the 10th and 12th degrees, the distribution and size of the primary effects constitute the most reliable indicator for the evaluation of intensity; below the $X$ degree, the detected effects are analyzed together with the damage indicators of other scales (in Italy, MCS, MSK, and EMS). The goal of the ESI scale is to best represent the macroseismic field of an earthquake according to environmental effects, which are comparable in a time window larger than that of instrumental data. Moreover, the effects on the environment do not depend on the socio-economic conditions of the investigated area.

Although the 2017 Casamicciola earthquake was a moderate size volcano-tectonic seismic event, we observed several ground effects both primary (surface ruptures and permanent displacement caused directly by the seismogenic source), and secondary (landslides, hydrological variations). The most important types of ground effects mapped during the field survey, were ground ruptures, fractures, landslides, variations in fumarolic activity, and dry wall collapses $[4,22,23]$.

Generally, the whole investigated area showed fractures (small open cracks with vertical offset $\leq 1 \mathrm{~cm}$ ), on both manmade structures and ground, on road and on ground cover, mostly WNW to E-W trending, and lengths up to some tens of meters (Figure 1). In addition, some coseismic ruptures in the soil and manmade structures were observed with maximum opening of $3 \mathrm{~cm}$ and in some cases a vertical offset of about $2 \mathrm{~cm}$ with appreciable displacement towards NNW.

Widespread sliding phenomena of drywalls, that are locally known as 'parracine', built mainly with green tuff and also with lava materials, were also observed, with a general 
direction of movement from south to north, as well as modest gravitational phenomena such as small size collapses of several $\mathrm{m}^{3}$, and small landslides in volcanoclastic deposits, along the northern slope of Mt. Epomeo [4,22]. The collapses of the 'parracine' are systematically located in the same zone affected by the fracturing of the soil. All types of effects are concentrated in a ca. E-W trending narrow band, $2 \mathrm{~km}$ long and less than a kilometer thick.

Moreover, an increase of steam emission in the Montecito fumaroles was observed soon after the 21 August 2017, mainshock, as witnessed and reported by the local inhabitants. According to [4], the distribution of coseismic effects defines an end-to-end $2 \mathrm{~km}$ long rupture, regarded as $\mathrm{N}$ dipping, primary surface normal faulting accompanying the 21 August 2017, volcano-tectonic event.

For the ESI macroseismic field reconstruction on Ischia island after the 2017 Casamicciola earthquake, we assessed intensity data from sites with observed environmental effect (114 data points, Figure 4), described in 48 detailed descriptive sheets and attached as supplementary files to this work (Table S1). The pattern of mapped coseismic ground effects is represented over all by $60 \%$ of ruptures and $16 \%$ of fractures; the secondary coseismic effects consisted in $12 \%$ of drywall collapses; $9 \%$ of landslides phenomena; $3 \%$ of steam variations in Montecito fumaroles [22] (Figure 4).

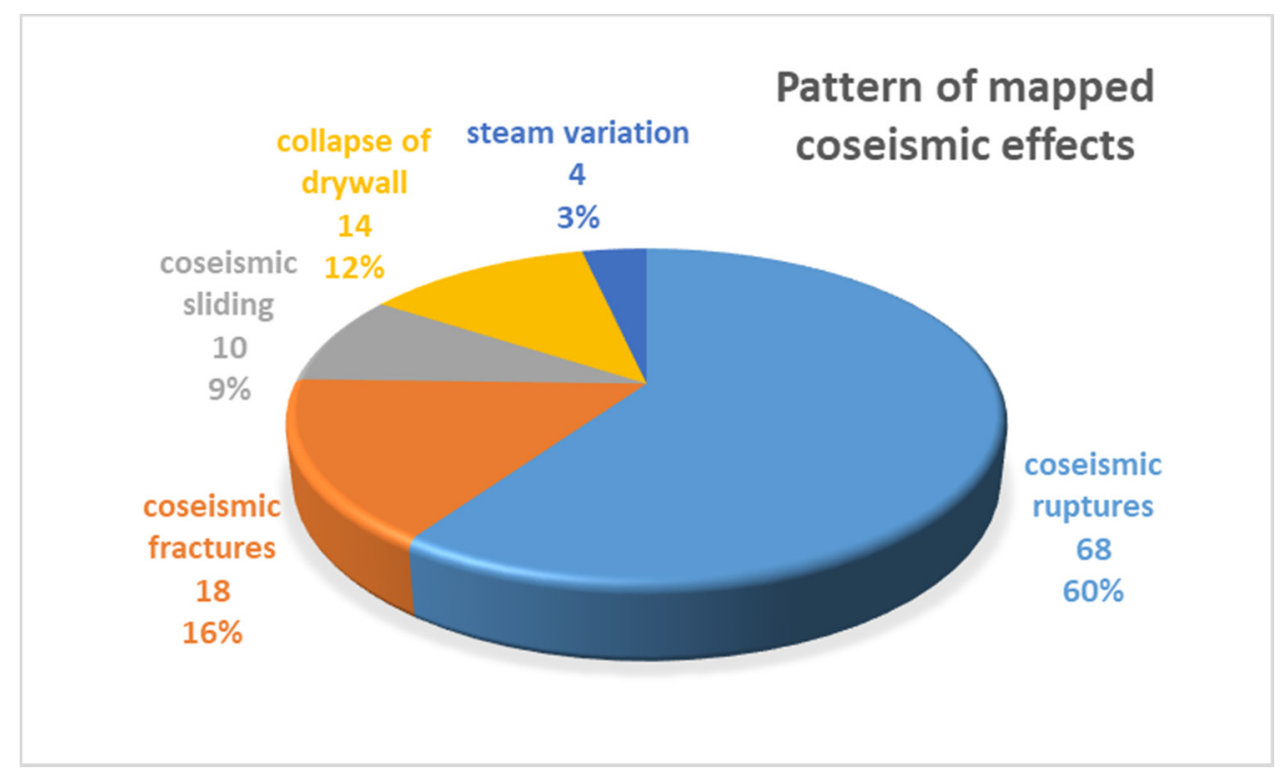

Figure 4. Diagram shows the pattern (number and percentage) of primary, secondary coseismic ground effects and collapse of drywall (data reported because located in the immediate vicinity of ground effects) mapped in the epicentral area immediately after the 21 August 2017 earthquake. Data from Table S1.

Considering the distribution (Figure 5) of the primary, secondary coseismic geological data and collapse of drywall (data reported because located in the immediate vicinity of ground effects) (Table S1), we have assessed the epicentral ESI intensity. We assigned the VII degree of ESI scale by taking into account the total length of the fault segment, about $2 \mathrm{~km}$, and the maximum displacement observed, about $2-3 \mathrm{~cm}$, as well as the area affected by others secondary coseismic effects, which is only of a few $\mathrm{km}^{2}$. The maximum degree of intensity detected I = VII ESI is in correspondence with the localities of Piazza Maio, La Rita, and Fango (Lacco Ameno) (Figures 1 and 2). 


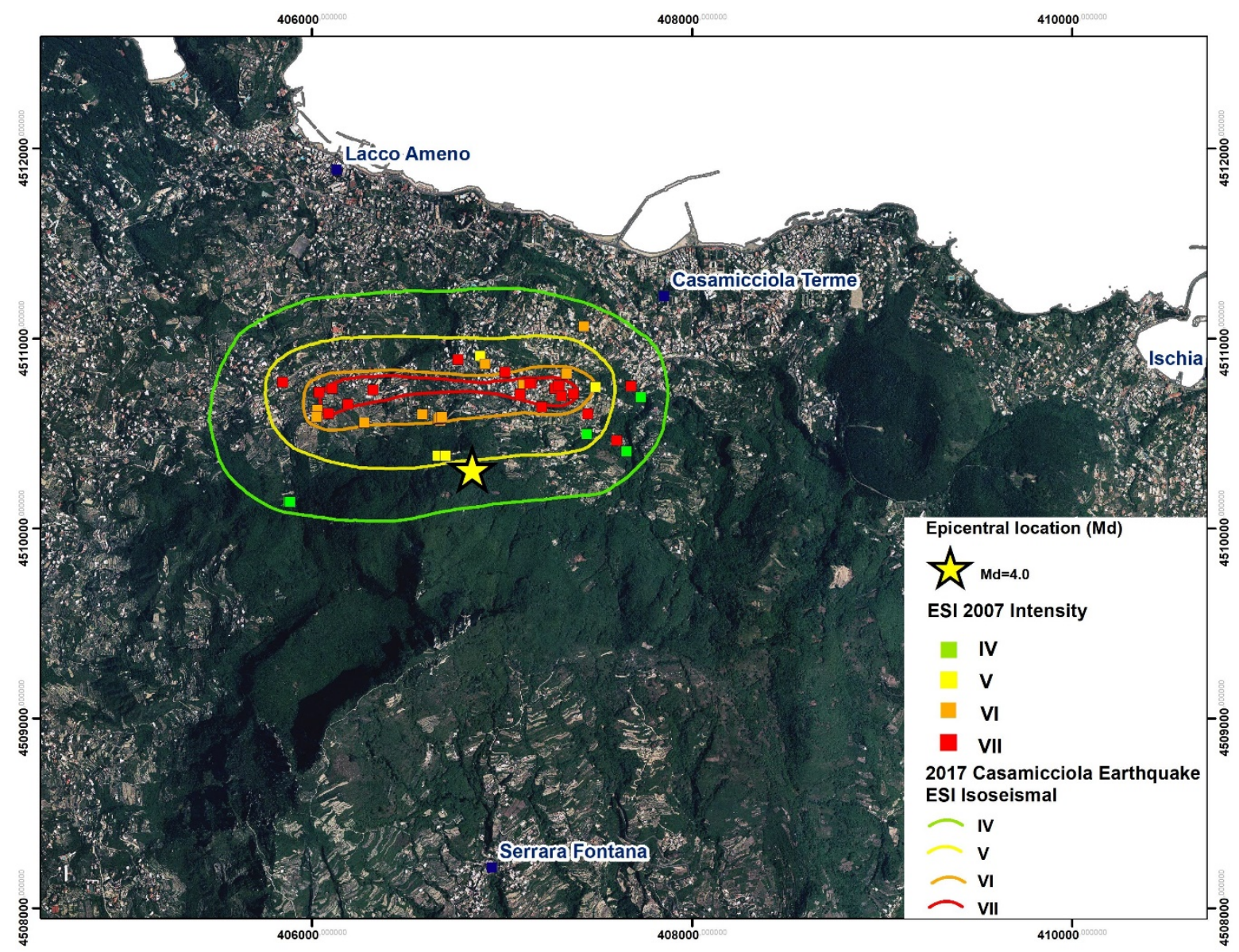

Figure 5. Isoseismals of the 21 August 2017, Casamicciola earthquake according to the ESI 2007 scale; the sites with environmental effects are described in the sheets available in the Table S1.

Based on the degrees of intensity assigned to the individual sites, it was possible to trace the isoseismal lines in Figure 5. The isoseismal that encompasses the VII degree has an elongated shape and includes an area of approximately $1000 \times 100 \mathrm{~m}$. Given the very shallow hypocenter, we argue that this isoseismal follows the causative normal fault of the 21 August 2017, earthquake. This result is in agreement with the mapped surface faulting, and with the geophysical model of the faults north of Mt. Epomeo [4,19,32]. The subsequent isoseismals are concentric and come to include an area of $2 \mathrm{~km}^{2}$, without reaching the coastal area of Casamicciola Terme, the center of Lacco Ameno, and the other small cities of the island. The macroseismic field has a limited extension, in which the rapid attenuation of intensity is observed, even in a few kilometers.

\section{Discussion}

We assessed the macroseismic field of the 21 August 2017 Casamicciola earthquake according to the ESI scale, analyzing the literature data, especially the results published in $[4,32]$. We compiled the primary and secondary effects assigning ESI intensity values for each site in order to create the isoseismal map of the earthquake (Figure 5).

From the analysis of the macroseismic intensity field, the concentration of environmental coseismic effects and severe damage can be observed in a restricted area north of $\mathrm{Mt}$. Epomeo, at the epicenter. The intensity assignments with traditional scales show that the less severe effects on anthropic structures are visible in particular far from the epicentral area, and limited to the rest of the island [5-8] (Figure 6). 


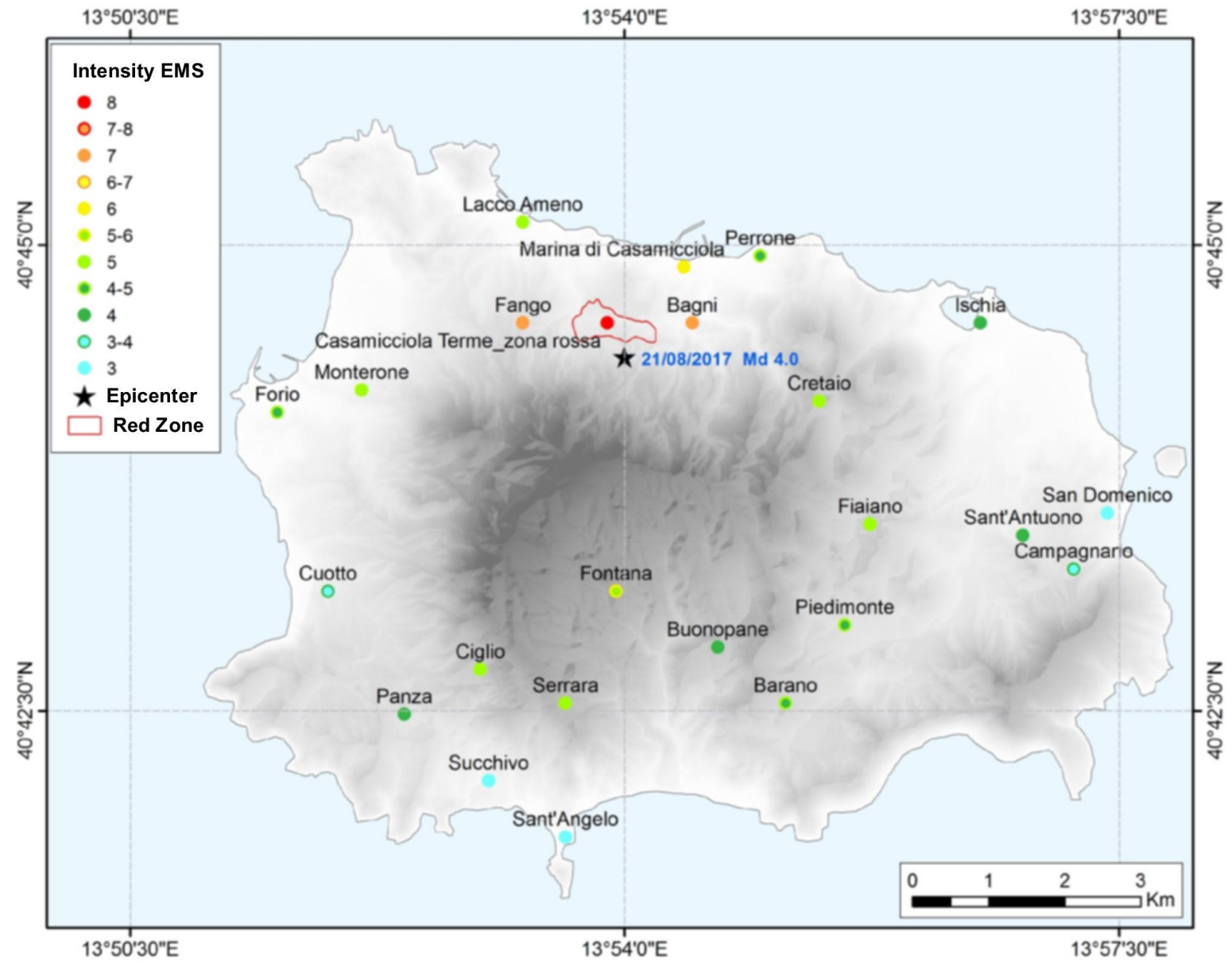

Figure 6. EMS scale intensity map of the 21 August 2017, earthquake [6]; compare with Figure 5 and note that the ESI 2007 isoseismals are concentrated in the "zona rossa" (the "red zone" with heavy damage) and nearby area along the base of Mt. Epomeo N slope; no environmental effect has been reported in the rest of the Ischia Island.

The spatial distribution of the environmental effects of the earthquake (EEE) and the isoseismal map confirms that the area between Fango (Lacco Ameno) and Piazza Bagni localities (Figures 2 and 5) is the epicentral area. It is important to note that in the epicentral area of damaging earthquakes, when compared with traditional intensity scales the ESI intensity map generally shows a steeper attenuation in the near field (e.g., [27,69]). Therefore, ESI intensity typically provides better constraints on the location and geometry of the seismic source.

In fact, the ESI isoseismals in Figure 5 suggest a location of the seismic source that is in agreement with the seismotectonic model hypothesized by [4], with an E-trending, $\mathrm{N}$-dipping normal fault associated with the well-known E-W Holocene extensional system responsible of the uplift of the $\mathrm{N}$ flank of Mt. Epomeo [9,16] (Figure 7a). This is consistent also with the hypothesis of a source model for the 2017 Casamicciola earthquake made using InSar data $[17,70]$, showing a shear fault, E-W oriented, N-dipping, with a pure normal mechanism and an average seismic slip of $\sim 13 \mathrm{~cm}$ (Figure $7 \mathrm{~b}$ ). The comparison between measured and computed ground deformations (Figure 7) highlights a fairly good correlation therefore the modelled deformation amplitude is similar to the coseismic observations. A similar model was first introduced by [71] before the seismic event, taking into account the available geodetic data and the behavior of the hydrothermal system located along the Mt. Epomeo N flank. New modeling of the integrated seismic and geodetic dataset available after the event also confirms this geometry and kinematic of the Casamicciola Terme shallow hydrothermal earthquake source [19]. 


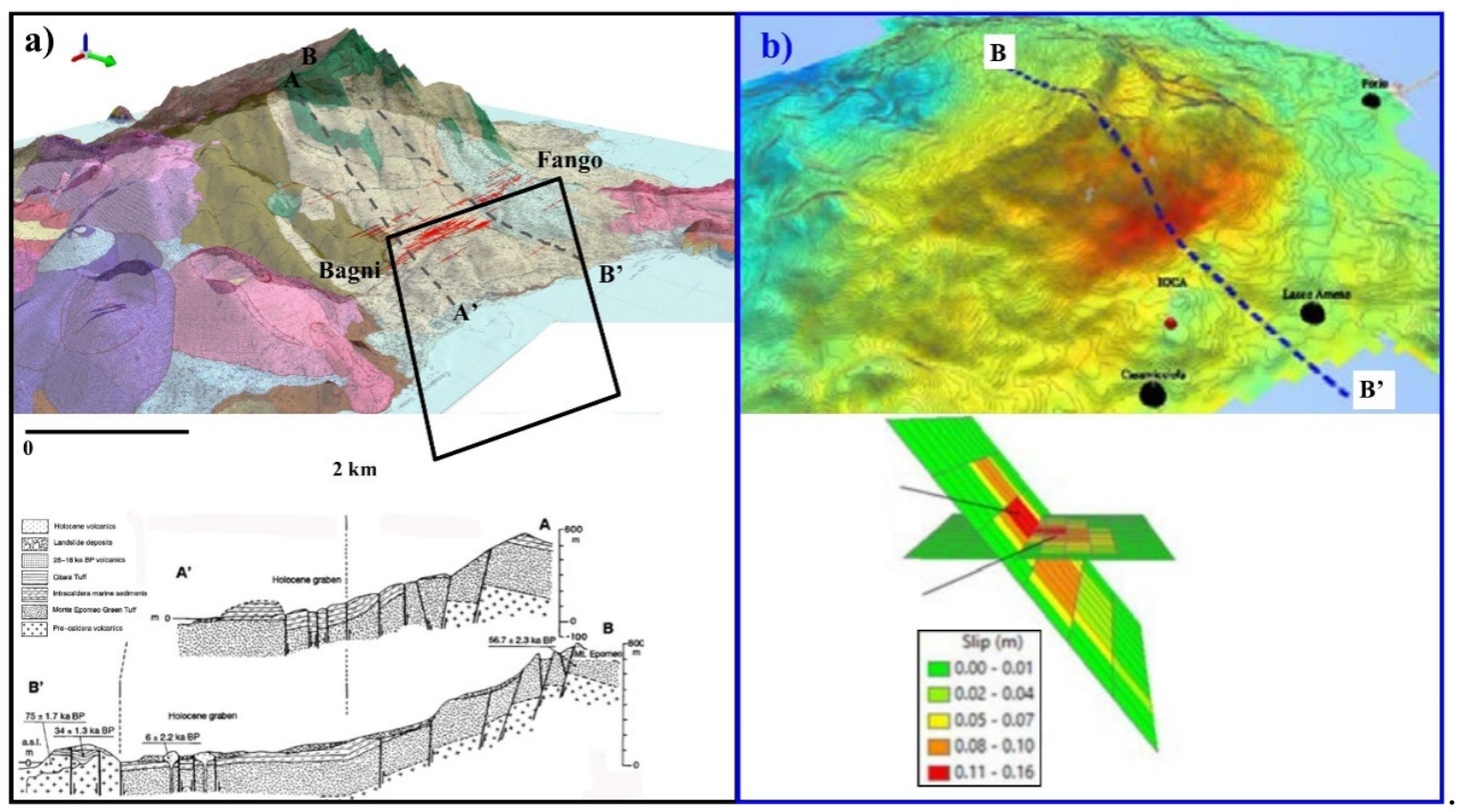

Figure 7. Comparison between the observed (on the left) and InSar modeled deformation due to the 2017 Casamicciola earthquake; (a) geological map of [16] overlapped on the 3D terrain model of Ischia island; note the trace of geological sections $\mathrm{A}^{\prime} \mathrm{A}$ and $\mathrm{B}^{\prime} \mathrm{B}$ shown on the bottom [32]; the black rectangle represents the fault plane of the 2017 Casamicciola earthquake source, as defined in the present study; (b) on the top, InSAR surface deformations along the section B-B' on the flank of Mt. Epomeo and on the bottom, the [70] analytic model of the 2017 Casamicciola source.

\section{Conclusions}

We analyzed the macroseismic intensity of the 21 August 2017, Md 4.0, Casamicciola Terme earthquakes using the ESI scale, and generated a new isoseismal map (Figure 5). This allows to better constrain the causative fault for this shallow focus, damaging event, in agreement with previous studies modelling the source as a shallow, E-trending, N-dipping normal fault located between Bagni and Fango, capable to generate a $2 \mathrm{~km}$ long surface rupture (e.g., $[4,32,70])$. Integrated models based on geological, geodetic and seismological datasets are the best tool for unravelling the seismic behavior along the $\mathrm{N}$ slope of $\mathrm{Mt}$. Epomeo, which is clearly controlled by the local hydrothermal system [19,32,71].

This is also the proper methodological approach for seismic hazard assessment in the Ischia Island, exposed to high seismic risk due to the extremely high population density and outstanding tourism industry. We can state that the heavy damages in Casamicciola Terme and Lacco Ameno (I = VIII EMS; [5,6,8]), appear to be strictly related to the trace of the observed surface faulting, therefore clearly influenced by the geometry of the seismic source. From the spatial distribution of structural damage, we concluded that the areas belonging to the active and capable fault system are not suitable for construction foundation. The presence of the very shallow seismic source, that might be reactivated with future earthquakes, greatly influence the physical and mechanical characteristics of the rockmass. Through this study, a more complete picture of the vulnerability of the physical environment is obtained with respect to seismic events with a very shallow hypocenter, typical of Ischia.

Furthermore, the application of the ESI scale to the 21 August 2017, Casamicciola Terme earthquake is useful for comparing with the destructive historical seismic events that occurred in Casamicciola, and mitigate the risk from their repetition in the future. The evaluation of the seismic hazard can be expanded in space and time through the use of the ESI scale and the assignment of intensities which are fundamental because allow to reduce the uncertainty implicit in the ground motion attenuation laws. The proposed active and capable fault along the $\mathrm{N}$ slope of Mt. Epomeo is not present in the DISS database 
(Database of Individual Seismic Sources; [72]) nor in the ITHACA catalogue of capable faults (Italy Hazard from Capable Faults, [73]) for Italy. The DISS database includes in fact an unrealistic NE-trending seismic source based on the Boxer algorithm [74] in a volcano tectonic environment which is clearly not suitable for a similar application.

We argue that the time is ripe for a joint effort in order to redefine ground motion and ground rupture hazard at Ischia Island. This must include a new intensity prediction equation specific for the Ischia volcano, also with the integration of MCS, EMS, and ESI datasets, upgrading the approach already successfully tested at Mt. Etna volcano [75-77].

Supplementary Materials: The following are available online at https:/ /www.mdpi.com/2076-326 3/11/2/44/s1, Table S1: Descriptive sheet of the environmental effects allowed the estimation of the degrees of ESI intensity and the reconstruction of the isoseismal map.

Author Contributions: Conceptualization, S.P., R.N., and A.M.M.; Methodology, S.P. and A.M.M.; Software, R.N., M.F.F., and E.P.; Validation, A.M.M., S.P., R.N., and E.P.; Formal analysis, E.P.; Investigation, R.N., S.P., E.P., and A.M.M.; Data curation, R.N., A.M.M., S.P., L.V., G.G., M.F.F., and G.A.; Writing—original draft preparation, R.N., A.M.M., and S.P.; Review and editing, L.V., G.G., G.A., M.F.F., A.M.M., R.N., and S.P. All authors have read and agreed to the published version of the manuscript.

Funding: This research received no external funding.

Acknowledgments: The authors are grateful to anonymous reviewers for their constructive comments.

Conflicts of Interest: The authors declare no conflict of interest.

\section{References}

1. Gruppo di Lavoro INGV sul Terremoto Dell'isola di. Ischia Rapporto di Sintesi Preliminare sul Terremoto Dell'isola D'ISCHIA (Casamicciola) M4.0 del 21 agosto 2017 (6 Septembre 2017); INGV: Napoli, Italy, 2017. [CrossRef]

2. De Novellis, V.; Carlino, S.; Castaldo, R.; Tramelli, A.; De Luca, C.; Pino, N.A.; Pepe, S.; Convertito, V.; Zinno, I. The 21st August 2017 Ischia (Italy) earthquake source model inferred from seismological, GPS and DInSAR measurements. Geophys. Res. Lett. 2018, 45, 1-10. [CrossRef]

3. Braun, T.; Famiani, D.; Cesca, S. Seismological constraints on the source mechanism of the damaging seismic event of 21 August 2017 on Ischia Island (Southern Italy). Seismol. Res. Lett. 2018, 89, 1741-1749. [CrossRef]

4. Nappi, R.; Alessio, G.; Gaudiosi, G.; Nave, R.; Marotta, E.; Siniscalchi, V.; Civico, R.; Pizzimenti, L.; Peluso, R.; Belviso, P.; et al. The 21 August 2017 Md 4.0 Casamicciola Earthquake: First Evidence of Coseismic Normal Surface Faulting at the Ischia Volcanic Island. Seismol. Res. Lett. 2018, 89, 1323-1334. [CrossRef]

5. Azzaro, R.; Del Mese, S.; Martini, G.; Paolini, S.; Screpanti, A.; Verrobbi, V.; Tertulliani, A. QUEST-Rilievo Macrosismico Dell'isola di Ischia del 21 agosto 2017; Rapporto Interno INGV: Roma, Italy, 2017. [CrossRef]

6. Azzaro, R.; Tertulliani, A.; Del Mese, S.; Graziani, L.; Maramai, A.; Martini, G.; Paolini, S.; Screpanti, A.; Verrubbi, V.; Arcoraci, L. Il Terremoto di Casamicciola (Ischia) del 21 Agosto 2017: Effetti Macrosismici e Confronto con la Sismicità Storica Dell'area. In Proceedings of the $36^{\circ}$ GNGTS, Trieste, Italy, 14-16 November 2017; Available online: http:/ /www3.ogs.trieste.it/gngts/files/20 17/S11/Riassunti/Azzaro.pdf (accessed on 15 December 2020).

7. Iervolino, I.; Baltzopoulos, G.; Chioccarelli, E. Preliminary Engineering Report on Ground Motion Data of the 21 August 2017 Ischia Earthquake V3.0. 2017. Available online: http:/ / www.reluis.it (accessed on 1 December 2020).

8. Briseghella, B.; Demartino, C.; Fiore, A.; Nuti, C.; Sulpizio, C.; Vanzi, I.; Fiorentino, G. Preliminary data and field observations of the 21st August 2017 Ischia earthquake. Bull. Earthq. Eng. 2019, 17, 1221-1256. [CrossRef]

9. Vezzoli, L. Island of Ischia, in Quaderni de la Ricerca Scientifica; Vezzoli, L., Ed.; Consiglio Nazionale delle Ricerche: Roma, Italy, 1988; pp. 1-122.

10. Tibaldi, A.; Vezzoli, L. The space problem of caldera resurgence; an example from Ischia Island, Italy. Geol. Rundsch. 1998, 87, 53-66. [CrossRef]

11. Sbrana, A.; Marianelli, P.; Pasquini, G. Volcanology of Ischia (Italy). J. Maps 2018, 14, 494-503. [CrossRef]

12. Acocella, V.; Funiciello, R. The interaction between regional and local tectonics during resurgent doming: The case of the island of Ischia, Italy. J. Volcanol. Geoth. Res. 1999, 88, 109-123. [CrossRef]

13. Nappi, R.; Alessio, G.; Bellucci Sessa, E. A case study comparing landscape metrics to geologic and seismic data from the Ischia Island (southern Italy). Appl. Geomat. 2010, 2, 73-82. [CrossRef]

14. De Vita, S.; Sansivero, F.; Orsi, G.; Marotta, E.; Piochi, M. Volcanological and structural evolution of the Ischia resurgent caldera (Ischia) over the past $10 \mathrm{ka}$. Geol. Soc. Am. 2010, 464, 193-239.

15. Alessio, G.; Esposito, E.; Ferranti, L.; Mastrolorenzo, G.; Porfido, S. Correlazione tra sismicità ed elementi strutturali nell'isola di Ischia. Quaternario 1996, 9, 303-308. 
16. Sieberg, A. Geologie der Erdbeben. Handb. Geophys. 1930, 2, 552-555.

17. Albano, M.; Saroli, M.; Montuori, A.; Bignami, C.; Tolomei, C.; Polcari, M.; Pezzo, G.; Moro, M.; Atzori, S.; Stramondo, S.; et al. The relationship between InSAR coseismic deformation and earthquake-induced landslides associated with the 2017 Mw 3.9 Ischia (Italy), earthquake. Geoscience 2018, 8, 303. [CrossRef]

18. Ricco, C.; Alessio, G.; Aquino, I.; Brandi, G.; Brunori, C.A.; D’Errico, V.; Dolce, M.; Mele, G.; Nappi, R.; Pizzimenti, L.; et al. High precision leveling survey following the Casamicciola earthquake of 21 August 2017 (Ischia, Southern Italy): Field data and preliminary interpretation. Ann. Geophys. 2018, 61, GD665. [CrossRef]

19. Calderoni, G.; Di Giovambattista, R.; Pezzo, G.; Albano, M.; Atzori, S.; Tolomei, C.; Ventura, G. Seismic and geodetic evidences of a hydrothermal source in the Md 4.0, 2017, Ischia earthquake (Italy). J. Geophys. Res. Solid Earth 2019, 124, 5014-5029. [CrossRef]

20. Selva, J.; Acocella, V.; Bisson, M.; Caliro, S.; Costa, A.; Della Seta, M.; Martino, S. Multiple natural hazards at volcanic islands: A review for the Ischia volcano (Italy). J. Appl. Volcanol. 2019, 8, 5. [CrossRef]

21. Trasatti, E.; Acocella, V.; Di Vito, M.A.; Del Gaudio, C.; Weber, G.; Aquino, I.; Caliro, S.; Chiodini, G.; de Vita, S.; Ricco, C.; et al. Magma degassing as a source of long term seismicity at volcanoes: The Ischia island (Italy) case. Geophys. Res. Let. 2019, 46, 14421-14429. [CrossRef]

22. Nappi, R.; Nave, R.; Gaudiosi, G.; Alessio, G.; Siniscalchi, V.; Marotta, E.; Civico, R.; Pizzimenti, L.; Peluso, R.; Belviso, P.; et al. Coseismic evidence of surface faulting at the Ischia Volcanic Island after the 21 August 2017 Md 4.0 Casamicciola Earthquake. Pangaea 2020. [CrossRef]

23. Emergeo Working Group. A photographic collection of the coseismic geological effects induced by the 21 August 2017, M=4, Casamicciola earthquake (Ischia island, Italy). MISC 2019, 50, 194.

24. Keller, E.A.; Pinter, N. Active Tectonics_Earthquakes, Uplift and Landscape; Prentice Hall: Upper Saddle River, NJ, USA, 2002; pp. 33-35. ISBN 0-13-088230-5.

25. Michetti, A.M.; Esposito, E.; Gurpinar, J.; Mohammadioun, A.; Porfido, S.; Rogozhin, E.; Serva, L.; Tatevossian, R.; Vittori, E.; Audemard, F.; et al. The INQUA Scale. An Innovative Approach for Asses Sign Earthquake Intensities Based on SeismicallyInduced Ground Effects- in Natural Environment; Special paper APA. In Memorie Descrittive Della Carta Geologica d'Italia; Vittori, E., Comerci, V., Eds.; SystemCart: Roma, Italy, 2004; Volume 68, p. 115.

26. Michetti, A.M.; Esposito, E.; Guerrieri, L.; Porfido, S.; Serva, L.; Tatevossian, R.; Vittori, E.; Audemart, F.; Azuma, T.; Clague, J.; et al. Environmental Seismic Intensity Scale 2007- ESI 2007. In Memorie Descrittive della Carta Geologica d’Italia; Servizio Geologico d'Italia- Dipartimento Difesa del Suolo, APAT: Roma, Italy, 2007; Volume 74, pp. 7-54.

27. Serva, L.; Vittori, E.; Comerci, V.; Esposito, E.; Guerrieri, L.; Michetti, A.M.; Mohammadioun, B.; Mohammadioun, G.; Porfido, S.; Tatevossian, R.E. Earthquake hazard and the Environmental Seismic Intensity (ESI) scale. Pure Appl. Geophys. 2016, 173, 1479-1515. [CrossRef]

28. Azzaro, R.D.; Bella, L.; Ferreli, M.A.M.F.; Santagati, L.S.; Vittori, E. First study of fault trench stratigraphy at Mt. Etna volcano, Southern Italy: Understanding Holocene surface faulting along the Moscarello fault. J. Geodyn. 2000, 29, 187-210. [CrossRef]

29. Ferreli, L.; Michetti, A.M.; Serva, L.; Vittori, E. Stratigraphic Evidence of Coseismic Faulting and Aseismic Fault Creep from Exploratory Trenches at Mt. Etna volcano (Sicily, Italy). In Ancient Seismites: Boulder; Special Paper; Ettensohn, F.R., Rast, N., Brett, C.E., Eds.; Geological Society of America: Boulder, CO, USA, 2002; pp. 49-62.

30. Cubellis, E.; Luongo, G. Il Contesto Fisico, in AA.VV., il Terremoto del 28 luglio 1883 a Casamicciola nell'isola di Ischia. Presidenza Consiglio dei Ministri, Servizio Sismico Nazionale; Poligrafico e Zecca dello Stato: Roma, Italy, 1998; pp. 49-123.

31. Cubellis, E.; Luongo, G. History of Ischian Earthquakes; Bibliopolis: Naples, Italy, 2018.

32. Nappi, R.; Alessio, G.; Gaudiosi, G.; Nave, R.; Marotta, R.E.; Siniscalchi, V.; Civico, R.; Pizzimenti, L.; Peluso, R.; Belviso, P.; et al. Reply to "Comment on 'The 21 August 2017 Md 4.0 Casamicciola Earthquake: First Evidence of Coseismic Normal Surface Faulting at the Ischia Volcanic Island'by)" by V. De Novellis, S.; Carlino, R.; Castaldo, A.; Tramelli, C. De Luca, NA Pino, S.; Pepe, V.; Convertito, I.; Zinno, P. De Martino, M.; Bonano, F.; Giudicepietro, F.; Casu, G.; Macedonio, M.; Manunta, M.; Manzo, G.; Solaro, P.; Tizzani, G. Zeni, and R. Lanari. Seism. Res. Letters 2019, 90, 316-321.

33. Vezzoli, L.; Principe, C.; Malfatti, J.; Arrighi, S.; Tanguy, J.-C.; Le Goff, M. Modes and times of caldera resurgence: The <10 ka evolution of Ischia Caldera, Italy, from high-precision archaeomagnetic dating. J. Volc. Geoth. Res. 2009, 186, 305-319. [CrossRef]

34. Serva, L. History of the Environmental Seismic Intensity Scale ESI-07. Geosciences 2019, 9, 210. [CrossRef]

35. D'Amico, V.; Albarello, D. SASHA: A computer program to assess seismic hazard from intensity data. Seism. Res. Lett. 2008, 79, 663-671. [CrossRef]

36. Pasolini, C.; Gasperini, P.; Albarello, D.; Lolli, B. The attenuation of seismic intensity in Italy part I: Theoretical and empirical backgrounds. Bull. Seism. Soc. Am. 2008, 98, 682-691. [CrossRef]

37. Pasolini, C.; Albarello, D.; Gasperini, P.; D'Amico, V.; Lolli, B. The attenuation of seismic intensity in Italy part II: Modelling and validation. Bull. Seismol. Soc. Am. 2008, 98, 692-708. [CrossRef]

38. Rittman, A. Geologie der Insel Ischia; Erganzung Band: Berlin, Germany, 1930; Volume 6, p. 268.

39. Gillot, P.Y. The Recent Volcanic Activity in the Gulf of Naples: Compared Evolution of Ischia and Phlegraean Fields. In Proceedings of the IAVCEI Scientific Assembly, Giardini di Naxos, Italy, 16-21 September 1985; pp. 25-35.

40. Orsi, G.; Gallo, G.; Zanchi, A. Simple- shearing block resurgence in caldera depressions. A model from Pantelleria and Ischia. J. Volcan. Geotherm. Res. 1991, 47, 1-11. [CrossRef] 
41. De Vita, S.; Sansivero, F.; Orsi, G.; Marotta, E. Cyclical slope instability and volcanism related to volcano- tectonism in resurgent calderas: The Ischia island (Italy) case study. Eng. Geol. 2006, 86, 148-165. [CrossRef]

42. Fusi, N.; Tibaldi, A.; Vezzoli, L. Vulcanismo, risorgenza intracalderica e relazioni con la tettonica regionale nell'isola di Ischia. Mem. Soc. Geol. It. 1990, 45, 971-980.

43. Molin, P.; Acocella, V.; Funicello, R. Structural, seismic and Hydrothermal features at the border of an active intermittent resurgent block, Ischia island (Italy). Geotherm. Res. 2003, 121, 65-81. [CrossRef]

44. Carlino, S.; Cubellis, E.; Luongo, G.; Obrizzo, F. On the mechanics of caldera resurgence of Ischia island (southern Italy). In Mechanisms of Activity and Unrest at large Calderas; Special Pubblications; Geological Society: London, UK, 2006; Volume 269, pp. 181-193.

45. Paoletti, V.; Di Maio, R.; Cella, F.; Florio, G.; Motschka, K.; Roberti, N.; Secomandi, M.; Supper, R.; Fedi, M.; Rapolla, A. The Ischia volcanic island (southern Italy), Interferences from potential field. J. Volcanol. Geotherm. Res. 2009, 179, 69-86. [CrossRef]

46. Sbrana, A.; Fulignati, P.; Bovce, A.J.; Cecchetti, A. Exhumation of an active magmatic-hydrothermal system in a resurgent caldera environment. The example of Ischia island (Italy). Geol. Soc. Lond. 2009, 166, 1061-1073. [CrossRef]

47. Carlino, S. The process of resurgence for Ischia island (southern Italy) since $55 \mathrm{ka}$ : The laccolith model and implications for eruption forecasting. Bull. Volcanol. 2012, 74, 947-961. [CrossRef]

48. Tibaldi, A.; Vezzoli, L. A new type of volcano flank failure: The resurgent caldera sector collapse, Ischia, Italy. Geophys. Res. Lett. 2004, 31, L14605. [CrossRef]

49. Barra, A.D.; Cinque, A.; Italiano, A.; Scorziello, R. Il Pleistocene superiore marino di Ischia: Paleoecologia e rapporti con l'evoluzione tettonica recente. Studi Geol. Camerti 1992, 231-243. [CrossRef]

50. Manzo, M.; Ricciardi, G.P.; Casu, F.; Ventura, G.; Zeni, G.; Borgstrom, S.; Berardino, P.; Gaudio, D.C.; Lanari, R. Surface deformation analysis in the Ischia Island (Italy) based on space borne radar interferometry. J. Volcanol. Geoth. Res. 2006, 151, 399-416. [CrossRef]

51. Del Gaudio, C.; Aquino, I.; Ricco, C.; Sepe, V.; Serio, C. Monitoraggio geodetico dell'isola di Ischia: Risultati della livellazione geometrica di precisione eseguita a giugno 2010. Quad. Geofis. 2011, 87, 4-16.

52. Castaldo, R.; Gola, G.; Santilano, A.; De Novellis, V.; Pepe, S.; Manzo, M.; Tizzani, P. The role of thermo-rheological properties of the crust beneath Ischia Island (southern Italy) in the modulation of the ground deformation pattern. J. Volcanol. Geoth. Res. 2017, 344, 154-173. [CrossRef]

53. Johnston-Lavis, H.J. Monograph of the Earthquakes of Ischia; Dulai anc Co.: London, UK, 1885; pp. 1-122.

54. Mercalli, G. Sulla natura del terremoto ischiano del 28 luglio 1883, Rendiconti del R. Ist. Lomb. 1884, 17, 842-856.

55. Mercalli, G. L'isola d'Ischia ed il terremoto del 28 luglio 1883. Mem. Reg. Ist. Lomb. Sci. Lett. 1884, 6, 99-154.

56. D'Auria, L.; Giudicepietro, F.; Tramelli, A.; Ricciolino, P.; Bascio, D.L.; Orazi, M.; Martini, M.; Peluso, R.; Scarpato, G.; Esposito, A. The seismicity of Ischia Island. Seism. Res. Lett. 2018, 89, 1750-1760. [CrossRef]

57. Mele, R.; Del Prete, S. Fenomeni di instabilità dei versanti in Tufo Verde del Monte Epomeo (Isola d'Ischia-Campania). Boll. Soc. Geol. Ital. 1998, 117, 93-112.

58. Violante, C.; Budillon, E.; Esposito, E.; Porfido, S.; Vittori, E. Submerged hummocky topographies and relations with landslides on the northwestern flank of Ischia Island, Southern Italy. In Proceedings of the Proc. Int. Workshop on Occurrence and Mechanisms of Flow-Like Landslides in Natural Slopes and Earthfills, Sorrento, Italy, 14-16 May 2003; pp. 309-315.

59. Della Seta, M.; Marotta, E.; Orsi, G.; De Vita, S.; Sansivero, F.; Fredi, P. Slope instability induced by volcano-tectonics as an additional source of hazard in active volcanic areas: The case of Ischia island (Italy). Bull. Volcanol. 2012, 74, 79-106. [CrossRef]

60. Marmoni, G.M.; Martino, S.; Heap, M.J.; Reuschlé, T. Gravitational slope-deformation of a resurgent caldera: New insights from the mechanical behaviour of Mt. Nuovo tuffs (Ischia Island, Italy). J. Volcanol. Geoth. Res. 2017, 345, 1-20. [CrossRef]

61. Cubellis, E.; Carlino, S.; Ianuzzi, R.; Luongo, G.; Obrizzo, F. Management of Historical Seismic Data Using GIS: The island of Ischia (southern Italy). Nat. Hazard 2004, 33, 379-393.

62. Carlino, S.; Cubellis, E.; Marturano, A. The catastrophic 1883 earthquake at the island of Ischia (southern Italy): Macroseismic data and the role of geological conditions. Nat. Hazards 2010, 52, 231-247. [CrossRef]

63. Serenade Database, SEismic Restful ENAbled DatabasE. Available online: http://wessel.ov.ingv.it/serenade/ (accessed on 14 January 2021).

64. Cubellis, E.; Luongo, G.; Obrizzo, F.; Sepe, V.; Tammaro, U. Contribution to knowledge regarding the sources of earthquakes on the island of Ischia (Southern Italy). Nat. Hazards 2020, 100, 955-994. [CrossRef]

65. Luongo, G.; Carlino, S.; Cubellis, E.; Delizia, I.; Iannuzzi, R.; Obrizzo, F. Il Terremoto di Casamicciola del 1883: Una Ricostruzione Mancata; Alfa Tipografia: Napoli, Italy, 2006; p. 64.

66. Wood, H.O.; Neumann, F. Modified Mercalli intensity scale of 1931. Bull. Seism. Soc. Am. 1931, 21, $277-283$.

67. Medvedev, S.V. Seismic intensity scale MSK-76. Inst. Geophys. Pol. Acad. Sci. 1977, 117, 95.

68. European Macroseismic Scale 1998 (EMS-98). Cahiers du Centre Europèen de Gèodinamique et de Sèismologie 15; Grunthal, G. (Ed.) Centre Europèen de Gèodinamique et de Sèismologie: Luxembourg, 1998; p. 99.

69. Ferrario, M.F.; Livio, F.; Serra Capizzano, S.; Michetti, A.M. Developing the first Intensity Prediction Equation based on the Environmental Scale Intensity: A case study from strong normal faulting earthquakes in the Italian Apennines. Seismol. Res. Lett. 2020, 20, 1-13. [CrossRef] 
70. Montuori, A.; Albano, M.; Polcari, M.; Atzori, S.; Bignami, C.; Tolomei, C.; Salvi, S. Using Multi-Frequency InSAR Data to Constrain Ground Deformation of Ischia Earthquake. In Proceedings of the IGARSS 2018 IEEE International Geoscience and Remote Sensing Symposium, Valencia, Spain, 22-27 July 2018; pp. 541-544.

71. Sepe, V.; Atzori, S.; Ventura, G. Subsidence due to crack closure and depressurization of hydrothermal systems: A case study from Mt. Epomeo (Ischia Island, Italy). Terra Nova 2007, 19, 127-132. [CrossRef]

72. DISS Working Group Database of Individual Seismogenic Sources (DISS), Version 3.2.1: A Compilation of Potential Sources for Earthquakes Larger than M 5.5 in Italy and Surrounding Areas. Istituto Nazionale di Geofisica e Vulcanologia 2018. Available online: http:/ / diss.rm.ingv.it/diss / (accessed on 12 January 2021).

73. ITHACA Working Group ITHACA (ITaly HAzard from CApable Faulting). A Database of Active Capable Faults of the Italian Territory. Version December 2019. ISPRA Geological Survey of Italy, 2019. Available online: http://sgi2.isprambiente.it/ ithacaweb/Mappatura.aspx (accessed on 15 December 2020).

74. Gasperini, P.; Bernardini, F.; Valensise, G.; Boschi, E. Defining seismogenic sources from historical earthquake felt reports. Bull. Seis. Soc. Am. 1999, 89, 94-110.

75. Bella, D.; Tringali, G.; Pettinato, R.; Livio, F.; Ferrario, M.F.; Michetti, A.M.; Porfido, S.; Blumetti, A.M.; Di Manna, P.; Vittori, E.; et al. Earthquake Rupture on the Fiandaca Fault, Dec. 26, 2018, MW 4.9: Fault Fabric Analysis, Intensity vs. Surface Faulting, and Historical Seismicity at Mt. Etna Volcano, Italy. In Proceedings of the GNGTS, Roma, Italy, 12-14 November 2019; pp. 30-33, ISBN 978-88-940442-9-4.

76. Azzaro, R.; Barbano, M.S.; Amico, S.D.; Tuvè, T. The attenuation of seismic intensity in the Etna region and comparison with other Italian volcanic districts. Ann. Geophys. 2006, 49, 4-5.

77. Civico, R.; Pucci, S.; Nappi, R.; Azzaro, R.; Villani, F.; Pantosti, D.; Cinti, F.R.; Pizzimenti, L.; Branca, S.; Brunori, C.A.; et al. Surface ruptures following the 26 December 2018, Mw 4.9, Mt. Etna earthquake, Sicily (Italy) EMERGEO Working Group (Etna 2018). J. Maps 2019, 15, 831-837. [CrossRef] 